\title{
DRAMATIC TECHNIQUE IN FROST'S POETRY
}

\author{
Gol Man Gurung, PhD*
}

\begin{abstract}
Robert Frost's poetry is consolidation of theme, content, form, technique, and prosody. When words are forced into a strict prosody without apprehension of connotation, they become forced obstinate and merely clinking sounds. The combination of form, content, and music generate beauty in verse. By means of the use of dialogue and monologue, he gives genuine treatment to realistic situation in his poems. Three poems: "The Death of the Hired Man", "Stopping by Woods on a Snowy Evening" and "West Running Brook" present brilliance, vivacity, and a sense of exhilaration due to the dramatic techniques of presentation. The speaker in these poems should not be taken literally to represent Frost, rather a character who replies in typical ways to the world around him. The speaker is independent, lonely, and sensitive and he often yearns for acquaintance. The magnitude of his verse lies in its handling of man in relation to nature through dramatic technique.
\end{abstract}

Key Words: dialogue, monologue, nature, technique, verse

\section{Introduction}

Robert Frost's poetry exhibit the dramatic technique through dramatic monologue and dialogue between the characters. He does so to forward the action, develop characters and intensify a sense of reality and immediacy. Characters expose by what they say than by what they ensure. Dialogue stretches the imprint of practicality, boons interplay of ideas and dispositions and gives relief. Monologue on the other hand is a situation in which one person speaks, the person stands alone and speaks independently. Through monologue the poet discloses interior thoughts are. Robert Frost either uses dialogue or monologue to reveal the dramatic situation and highlight the attitudes of the characters toward reality. The greatness of the poet lies on the he perceives the same event from different perspectives. Frost has the quality of a poet as Lazar speaks that the reason for breaking the rules of traditional language, "Poetry frequently breaks the 'rules' of language, but bydoing so it communicates with us in a fresh, original way" (99). Glancytalks of the theme, "When we speak of a poem having a theme, we often referring to a poem that brings a particular human perspective to the subject matter" (vii). It gives readers a better understanding of society, social experiences, and emotions. The theme of the poem is likely to highlight human perspectives as Glancy articulates, "The beauty of nature, family dispute and the technique of presentation makes the poem a piece of art with unique quality. The verse gives joy by its syntactic deviation". Thornborrow\&Wareing advocate to analyze the "layout, number of lines, length of lines regular meter, rhyme, and sound patterning" (46). However, Frost is widely read not only because of the themes but due to the uniqueness hegenerates through dramatic techniques. Implied conversation magnets reader's courtesy to his verse.

* Associate Professor of Saraswati Multiple Campus (Humanities Faculty: English Department), Tribhuvan University, Nepal 


\section{Dramatic Technique in Frost's Poems}

This artefact examines the use of dramatic elements in the poems "The Death of the Hired Man", "Stopping By woods on a Snowy Evening", and West Running Brook". Dialogue and dramatic monologue are the two dramatic techniques that Frost uses in the three poems for the presentation of his love for nature and human life. The themes of these poems have been geared with the dramatic techniques: dialogue and dramatic monologue. The Death of the Hired Man" is a dialogue between husband and wife during the evening about the nature and character of a hired worker Silas. The poem begins with the homecoming of the family worker Silas:

Mary sat musing on the lamp-flame at the table

Waiting for Warren. When she heard his step

She ran on Tip-toe down the darkened passage

To meet him in the door way with the news

And put him on his guard "Silas is back" (Ferguson 324)

Mary shows her humanity and homely nature 'musing' and 'waiting for Warren' right from the beginning of the poem. She is aware of the fact that even the sound of the foot disturbs the worker who has come back having the sense of safety, security, and compassion, 'she ran on tip-toe', and dislikes to disturb Silas, the old man who has come back to Mary and Warren's house, helping Warren with his parcels and asking him to be kind, However Warren is not ready to accept Silas as a worker. His reply indicates that he is guided by reason, rationality, and practicality. The worker has to be present in need.

The conversation functions as the means of presenting ideas about the differing attitude to the family worker. The conflict between Mary and Warren in relation to their attitude to the people and world gets reflected through their words and way of thinking. Warren views that he is not ready to accept the "fellow back" whereas May pleads the husband to "be kind." The worker's home coming becomes the matter of argument. Warren has the logic that the worker left at the dire time, so he is not serious for the work, "off he goes when I need him most" but Mary pleads him to observer the existing situation of his health and comment him. Her attitude is guided by emotion whereas Warren is guided through reason. Their attitudes towards Silas, a hired man differs that reflects their views and visions. The opening lines present the instantaneous but accurate situation, suggest a conflict and clue at the nature of man and woman:

When was I ever anything but kind to him?

But I'll not have the fellow back" he said

I told him so last haying, didn't I? (Ferguson, 325)

Warren's reply reveals the nature of the conflict between employee and the boss and approximately of the character of both men. It also shows different attitude of Mary and Warren to Silas. Warren's speech rhythms are abrupt, indicating the displeasure at the fact that Silas has always port him during harvest time. Warren's reaction is self-protective for the point that he gives logic for firing the worker. His logic is based on pragmatism that worker has to be honest to his responsibility. In this poem, poetic discourse becomes the means of presenting perceptions about the differing attitude of male and female in relation to the household worker. After a long debate between husband and wife about Silas, the husband acknowledges Silas's ability and his 
attitude toward the old man changes. Mary sees the pathos and goodness of the hired man's life, his concern for other people, the lack of pride in his past life and the lack of hope for the future. Mary's statement is consistent with her earlier view, but Warren is moving to her way of thinking. The dialogue is interrupted by the narrative dimension at the end:

\section{It hit the moon}

Then there were three there, making a dim row

The moon the little silver cloud and she (Ferguson 328)

The poem benefits the movement of the moon setting in the west which is symbolic. The symbol is associated to trinity. Mary has intuitive understanding tender sympathy and its setting is related to the death. Warren's feelings have been changed considerably at the end. He realizes the basic kindness, and gains a fuller and more compassionate understanding of life and learns to accept the value and dignity of another human being. The immediate appeal of the poem "comes from his ability to recreate skillfully the kinds of sensations we have all experienced in real life situation" (Comely 12). The speaker is troubled and uncertain about the nature of the sleep and believes that he could find an answer from a woodchuck. Warren values morality and accountability but Mary has empathy for the worker.

Frost's next poem "Stopping By woods on a Snowy Evening" is a verse about a traveler's pausing during his travel in the evening to watch the exquisiteness of the natural beauty and his helplessness to spend a long time due to the obligation and responsibility he has to accomplish to the world and its people. The poet uses dramatic monologue to reveal the inner response to beauty. It is the description of a wood many of us have felt, the desire to stop in the midst of our busy lives to enjoy a moment of beauty:

Whose woods these are I think I know

His house is in the village though,

He will not see me stopping here

To watch his woods fill up with snow (85)

Nature is the prominent aspect of Frost's poems. This verse begins with the company of nature. "Whose woods these are I think I know." The last line of this stanza "woods fill up with snow" indicate the mesmerizing panorama of nature. The speaker begins the theatrical speech by disassociating himself from the owner of the wilderness. The proprietor of the land is in the hamlet and the speaker is alone. The speaker must be unaccompanied to have such heart closefitting involvement. The experience is such that other people in the village and society would not care about it. The society would not care about it. He has stopped far away from any human habitation, near the woods and lake in the middle of winter, to watch snow falling. His response to the quietness of the snow and dark depths of the woods is really appealing. The self- realization and revelation of nature leads him out of it. At the end of the poem, the speaker contemplates on the philosophical concept of life and death "Miles to go before I sleep." Human life has ups and downs. During this period, they have to complete their duty and responsibility. Beauty attracts the eye but responsibility hammers on head. Therefore, we cannot avoid both. The speaker learns himself exploring nature and its beauty. This monologue discovers how people get joy through social seclusion as the speaker does in the poem. 
In the poem "West Running Brook", two people, a husband and wife involve in a discourse. All the rivers generally flow to the sea but the poem deals with the river that flows to the west. This indicates that the poet has the willingness to go by antitheses. This dialogue reveals their differing tactics to life. The setting of the poem is in the country, and the action of the poem focuses on the character's reactions to nature. This poem convincingly highlights ideas about the nature of existence. The wife's opening speeches introduce the brook and her attitude to life after asking why this brook should run western when all the other in the area flow eastward, she states, "Fred where I north", then he responds "North? North is there, my love. "The poem begins with the conversation between husband and wife. The readers familiarize them with the setting of the poem through their dialogue-dramatic technique of the poem:

It must be the brook

Can trust itself to go by contraries

The way I can with you- and you with me (Ferguson 328 - 329)

Immediately after visualizing the situation the wife links their love and relationship with the river. The poem knockouts at the thematic tension. Wife sees the fact that the brook does not follow as others do as a symbol of the love in their marriage. She sees the symbol as the relationship with her husband and the undercurrent of existence. This dialogue leads the husband involve in the philosophical musing on human existence and human life. Love lies in trust of the both. It is united through the two companions' capability to faith and love each other even though the two partners' approach of life differs. River parallels "the mystical fact of their marriage because the flow of river appearances complications" (Scholes 32). The husband's reply is worded philosophically. The verse indicates that our life flows like a river and we feel that it is moving forward but in reality, it is contrary to this. The dialogue proceeds, "Long, long before we were from any creatures". He means to say the sense of rebirth and journey forward. We are moving back to death as "we were made in heaven". So, our life is not forward moving but backward moving. The philosophical ideas have been conveyed through dramatic technique. After clarification systematically that the backward moving wave in mid stream is created by the resistance of the water to the rock. The backward flowing wave signifies the life moving toward death. Finally, both of them come to a pint that contrariness generates movement in life. Human existence is supposed to move like the wave of the river having perversity. Love makes life meaningful notwithstanding the fact that there is contrariness.

\section{Conclusion}

"The Death of the Hired Man", "Stopping by Woods on a Snowy Evening" and "West Running Brook" make the theme feasible to the readers through the dramatic technique of presentation. The Death of the Hired Man presents the debate between husband and wife about Silas, a hired worker. Mary sees the bleakness and goodness of the employed man's life, but her husband concerns for practicality. Silas neither had pride in his past life nor hope for the future. Mary's statement is consistent with her earlier view, but Warren is moving to her way of thinking. The death of the hired man at the end turns the situation the other way round. "Stopping by Woods on a Snowy Evening" is a philosophical poem in which the speaker anticipates on the philosophical concept of life and death. Human life has different positive and vice versa activities. During this period, they have to complete their duty and responsibility. Attractiveness appeals the eye but 
accountability mallets on head. Therefore, we cannot avoid both. The speaker learns himself exploring nature and its beauty. This monologue discovers how people get joy through communal isolation as the speaker ensures in the poem.Through theatrical elements, the poet grants people's perception and response to the same situation from wide-ranging view point. The point of argument becomes the source of revelation of the human understanding to the world and its people reacting to realistic situations and these situations are capable of being given poetic treatment. "West Running Brook" is a poem with philosophical ideas that have been conveyed through dramatic technique. After explanation thoroughly that the regressive moving wave in mid-stream is shaped by the confrontation of the water to the rock. The backward flowing wave indicates the life moving toward death. Human existence is hypothetical to move like the wave of the river having perversity. Love makes life eloquent notwithstanding the fact that there is perversity. Like ice melting Frost's poetry generates its own lubricant. The poet creates the significance of the events and characters bringing them from down to earth reality. He interrelates his subject matter and poetic form in such a way that the finished work becomes a meaningful statement about reality. Examining his poetry is examining human life as it is. Deviated syntactic structure, parenthetical remarks, syntax directly reflect themes and techniques of the poet. Techniques of the poems, ideas, and writer's craft make him a noteworthy poet.

\section{Works Cited}

Comely, Nancy R. ed. Elements of Literature. Oxford Up, 1997.

Ferguson, Margaret, ed. The Norton Anthology of Poetry. California: U of C, 1995.

Glancy, R. Thematic Guide to British Poetry. London: Greenwood Press, 2002.

$<$ www.greenwood.com>

Lazar, G. Literature and Language Teaching. Cambridge: Cambridge University Press, 1993.

Scholes, R., Klaus, C.H., Silverman, M., \& Comley, N.R. Elements of Literature.4th Ed.Oxford and New York: Oxford University Press, 1991.

Thornborrow, J. \&Wareing, S. Pattern in Language. London and New York:Routledge, 1998. 